\title{
Gary Steiner
}

\section{Kathy Rudy's Feel-Good Ethics}

\section{Kathy Rudy, Loving Animals. Toward a New Animal Advocacy. Minneapolis: University of Minnesota Press, 2011. 288 pp. \$ 24.95 hc.}

I was watching an episode of Jeopardy a couple of months ago in which, during the postadvertisement banter with the host, a contestant who identified herself as a veterinary student said something to the effect that she "loves animals! Some of them I love to pet, and some of them I love to eat!" Given the evangelical tone of her recent book Loving Animals: Toward a New Animal Advocacy, one might be excused for supposing that Kathy Rudy pushes for something fundamentally different than the sentiments expressed by that Jeopardy contestant. And yet by the end of the book, one finds no meaningful difference between the two. Indeed, one finds in Rudy's book a conspicuous example of what Martha Nussbaum once called a troubling "self-serving inconsistency" in our judgments about the moral status of animals and what Gary Francione has characterized as our "moral schizophrenia" regarding animals. ${ }^{1}$

Rudy's aim in Loving Animals is to "undertake and attend to significant emotional shifts concerning animals for animal rights to become a more mainstream movement"; this requires a "step back from the rational principles employed by many animal advocacy philosophies to examine the emotional and spiritual connections that, for many, produced the desire for change in the first place" (x). Rather than proceeding from abstract rational reflections and the endeavor to articulate determinate principles governing our relationships to animals, we need "a more sophisticated understanding of the role of affect and emotion in the building of a contemporary animal advocacy movement" (xiii). Rudy hastens to note that this does not mean that reason should be sacrificed to emotion altogether. She acknowledges that "reason and emotion are inextricably intertwined" (xvi), and she correctly observes that "focusing entirely on emotion can quickly lead us to an impoverished sentimentality" (xvii). But instead of exploring the relationship between reason and emotion and considering the proper role of reason in moral reflection, Rudy develops a central argument that exhibits its own kind of impoverished sentimentality - one according to which husbanding, killing, eating, experimenting on, and perhaps even wearing animals is completely permissible, provided that we "love" them. 
The inner logic of Rudy's position is largely obscured by her proclamations, found on virtually every page, of profound love for animals. That logic proceeds from the proposition that because the lives of human beings and non-human animals are inextricably intertwined, it is unrealistic to pursue courses of action that would seek to separate the two. Following Donna Haraway, Rudy suggests that "human and nonhuman animals are enmeshed in a world that requires sacrifice on both parts.... [S] uch interconnection, even when it requires suffering, is sacred" (xix). This appeal to the sanctity of sacrifice loses its initial plausibility once it becomes clear that the only beings called upon in Rudy's world to make any real sacrifices are non-human animals. Apart from stories such as one about Rudy sitting in her car crying for hours when she had to find a new home for one of her dogs, or one about how the local farmers from whom Rudy obtains meat feel so very bad when they take their animals to the slaughterhouse, there is little if anything in this book that shows any recognition of or commitment to the prospect of human sacrifice on behalf of non-human animals.

For example, Rudy argues that, "given the shrinking space of the undeveloped 'wild' world, those animals that can learn to live in connection with humans may have the best chance for survival" (112). In other words, rather than stand idly by and let wild animals become extinct as human beings expand their dominion over the natural world, we ought to let private individuals keep wild animals such as lions and tigers in humane sanctuaries. To the objection that this kind of confinement would be a gross infringement on the liberty of wild animals, Rudy responds that the only relevant considerations are whether the animals are happy and whether they seem to be leading "fulfilled lives" (118). After all, Rudy visited a big-cat sanctuary and saw a group of lions playing with pumpkins (113). They were happy and fulfilled! Rudy never considers whether this is a rather myopic perspective on the situation in which those lions found themselves - one can imagine human convicts playing football on a prison yard and an unsophisticated observer remarking that the prisoners appear to be having a rousing good time.

Nor does Rudy even once consider the possibility that we human beings could endeavor to curtail our encroachments upon wild spaces, in order to leave wild animals what little dignity they may still be able to enjoy. Indeed her pragmatic orientation prevents her from doing so. She states continually in the book that radical approaches to the moral status of animals will never succeed; for example, "veganism is a radical lifestyle change that most of society will never embrace" (104). Thus Rudy would presumably say that it is unrealistic to expect human beings to make the enormous 
sacrifices that would be entailed by a call to preserve existing wild spaces. But if this is the case, then why should we suppose that human beings would be willing to make any of the large sacrifices that would be called for by her ethic of loving animals? Rudy never resolves this tension between resigned pragmatism and idealistic sentimentality in Loving Animals. Instead she pushes for a set of highly anthropocentric conclusions about the proper treatment of animals that share a great deal with the welfarist and utilitarian positions that she purports to find deficient.

Rudy pushes for her conclusions by rejecting abolitionism and the analogy that many abolitionists (myself included) draw between animal husbandry and slavery. Abolitionism mistakenly assumes that animals "are a kind of self-determined nonhuman subject that can operate in the world uncoerced by culture, the state, needs, desires, identity, commitments, or the necessities of everyday life" (5). But many human beings, Rudy observes, do not possess this kind of freedom; a fortiori it makes no sense to attribute it to non-human animals. Rather than seeking an ideal of total animal liberation from influence by human beings, we ought to recognize that domestication is a bargain made by some animals with human beings whereby animals sacrifice "some of their freedoms" in exchange for "food, shelter, belonging, and love" (5).

This gross mischaracterization of abolitionism is vital to Rudy's endeavor to argue for the permissibility of practices such as meat eating. Abolitionism expresses no necessary commitments regarding the kind of freedom animals possess, nor does it suppose that animals could ever live completely free of human interference - any more than liberal political theory, in proclaiming that human citizens have a fundamental right not to be interfered with by other citizens in the exercise of their freedom, supposes that no citizen will in fact ever be interfered with. What abolitionism argues is that animals possess the capacity for self-determination and have the right not to be interfered with in the conduct of their lives. Abolitionism never denies that different subjects are involved in mutual relationships with other subjects. What it does deny is that human subjects enjoy the prerogative to decide what is and is not in the interests of non-human animals, particularly when these decisions invariably cater to the desire of human beings to eat, wear, experiment upon, and otherwise use animals.

Nowhere is the desire to rationalize human prerogatives more evident in Loving Animals than in Rudy's defense of meat eating. Having rejected abolitionism on the unargued and extraordinarily dubious grounds that it would lead to the complete extinction of non-human animals (5f., 8, 192), Rudy makes the following claims: that the push for veganism is "part of what keeps rescuers from embracing a broader advocacy agenda"

Humanimalia: a journal of human/animal interface studies

Volume 3, Number 2 (Spring 2012) 
(61); that a strict vegan agenda ignores "the millions of Americans now seeking a better relationship with both earth and animals" (74); that the rightist appeal to inherent worth is "highly subjective" (99); and that "animals who have a happy, drug-free, and relatively long life can be ethically consumed, along with their products like eggs and milk, as long as those are harvested morally as well" (75). Rudy attempts to support this last claim by attributing to non-human animals a desire to sacrifice themselves for our gustatory pleasure: "Farm animals pay their dues in life with their products and flesh, but they would rather have lived and loved and played in the sun and the dirt and the rain, than not to be born at all" (99). The animals we slaughter for our meals "would want to pay us back for all the love we had given them in their lives" (77). I'm not quite as sure about all this as Rudy is. Josephine Donovan once suggested that "we should not kill, eat, torture, and exploit animals because they do not want to be so treated, and we know that. If we listen, we can hear them." 2 Here it becomes clear why Rudy is at pains to deny the analogy to slavery: If she acknowledges that husbandry is an encroachment on the freedom of animals comparable to the encroachment on human freedom constituted by slavery, she cannot make it look as if animals are clearly better off in conditions of subjection to human control. In this connection Richard Sorabji wonders whether a group of slaves would clearly be better off being maintained as slaves, if the alternative would be that "the enslaved race would dwindle." 3

Nobody can honestly purport to know what decision an animal would make if faced with the choice between existing to be killed for human enjoyment and not existing at all; nor should we rush to assume, as Rudy does, that all animals would make the same decision, namely to sacrifice themselves for human beings. My own position on the matter is that, in light of the fact that the vast majority of human beings have a pronounced interest in a certain outcome - consider the "millions of Americans," Rudy included, who are determined to eat meat and consume other animal products we ought to proceed from the assumption that the animals in the equation do not want to be sacrificed. "Rather than positing a rebuttable claim in favor of humans in cases of conflict with animals, we really ought to take as axiomatic a rebuttable presumption in favor of animals." 4 Such a presumption is intended to protect animals from the selfserving inconsistency and moral schizophrenia that characterize not only existing human-animal relations but also the world according to Kathy Rudy, who claims that "the question of whether it's ethical to kill animal for meat still haunts" her (95), but whose moral misgivings disappear altogether when she is overcome by the "fantastic" taste of the locally farmed meat she loves to eat (82). Rudy, who continually appeals to the revelatory power of narrative in helping us get our moral bearings, seeks to bolster 
her claims about the appropriateness of eating animal products by telling the sad story of her own year-long attempt to live as a vegan, a year during which by her own account she ate a steady diet of highly-processed vegan junk food, as if the only choices faced by human beings were vegan snack food or meat (75ff.). In passages such as this, if only against her own intention, Rudy shows narrative to have as many dangers as virtues. She also invokes the old saw that "some people need some amount of animal protein to thrive" and the feeble claim that veganism "lets people off the hook for all the other ways we oppress animals" (105). If only it did.

Rudy offers a comparable rationale for practices such as animal experimentation (157, 170f.), hunting (194f.), and the confinement of wild animals (151): that it is better for animals to exist and be "sacrificed" for the sake of human beings than not to exist at all, and that animals want to make this sacrifice for us. Rudy advances this logic against the background of a worldview according to which humans and animals are inextricably involved with one another in such a way that sacrifices on both sides are necessary. But Rudy says precious little about the sacrifices that human beings ought to make. I have noted already that she never considers the possibility that human beings ought to endeavor to lessen their impact on the natural world; instead, Rudy requires animals to accommodate themselves to our desires and (supposed) needs, as when she states that only those wild animals that could learn to live subject to domestication stand a chance of surviving in a world in which human beings are the dominant species (151). Nowhere does Rudy express any concern for the many animals that could or would not accommodate themselves to human beings. (By the same token, she never confronts the manifest contradiction between eating animals such as chickens and pigs, which she seems to love to eat, and the abhorrence with which she would presumably receive the recommendation that she eat her beloved pet dogs once they have lived a "sufficient" amount of time.) More importantly, nowhere does she suggest that human beings should learn to live in accordance with non-human animals' ways of being; she continually frames the problem as one of animals having to accommodate themselves to humans, which leaves me wondering exactly what sort of mutuality and reciprocity Rudy ultimately has in mind. Are we human beings required to make any real sacrifices on behalf of animals? Apparently we are not: we still get to eat animals, have them as pets, experiment on them, hunt them, in fact do pretty much everything we were doing to them before, provided that we do so "with love." And we may be glibly assured that this is all just fine with animals who, very conveniently for us, cannot register their disapproval in any manner that a typical human being would be forced to recognize to be disapproval.

Humanimalia: a journal of human/animal interface studies

Volume 3, Number 2 (Spring 2012) 
Rudy's brand of morality is what I call "feel-good ethics, ethical commitments and sensibilities that permit us to express general abhorrence at the treatment of oppressed groups such as animals but do not push us out of our comfort zones by requiring us to take concrete steps to ameliorate the oppression that we so abhor." ${ }^{5}$ Rudy, for her own part, maintains that by appealing to feeling rather than to cold rationality she is articulating an ethical view that does better justice to animals. "Affect," she believes, "begins not with an abstract commitment to a philosophical principle, but with love for and connection to other beings.... There [is] no way principles ... would work in resolving our conflicts. Life is too complicated and sometimes you have to put your principles aside to do what is right" (214). Notwithstanding her passing suggestion that reason and affect must mutually inform one another (215), Kathy Rudy has put reason and principles aside. But I am not convinced that she has done so in order to do what is right.

\section{Notes}

1. Martha C. Nussbaum. "Animal Rights: The Need for a Theoretical Basis" (review discussion of Steven M. Wise, Rattling the Cage: Toward Legal Rights for Animals). Harvard Law Review 114 (2001): 1548; Gary L. Francione. Introduction to Animal Rights: Your Child or the Dog? (Philadelphia: Temple UP, 2000). Ch. 1.

2. Josephine Donovan. "Animal Rights and Feminist Theory." Signs: Journal of Women in Culture and Society. 15.2 (Winter, 1990). 375.

3. Richard Sorabji. Animal Minds and Human Morals: The Origins of the Western Debate (Ithaca: Cornell UP, 1993). 215f.

4. Gary Steiner. Animals and the Moral Community: Mental Life, Moral Status, and Kinship (New York: Columbia UP, 2008). 109.

5. Gary Steiner. Animals and the Limits of Postmodernism (New York: Columbia UP, 2012, forthcoming). 